\title{
DISSOLUTION OF ZIRCONIUM ALLOY FUELS IN 309 SCb STAINLESS STEEL VESSELS
}

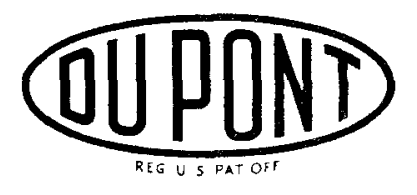

Savannah River Laboratory

Aiken, South Carolina 


\section{DISCLAIMER}

This report was prepared as an account of work sponsored by an agency of the United States Government. Neither the United States Government nor any agency Thereof, nor any of their employees, makes any warranty, express or implied, or assumes any legal liability or responsibility for the accuracy, completeness, or usefulness of any information, apparatus, product, or process disclosed, or represents that its use would not infringe privately owned rights. Reference herein to any specific commercial product, process, or service by trade name, trademark, manufacturer, or otherwise does not necessarily constitute or imply its endorsement, recommendation, or favoring by the United States Government or any agency thereof. The views and opinions of authors expressed herein do not necessarily state or reflect those of the United States Government or any agency thereof. 


\section{DISCLAIMER}

Portions of this document may be illegible in electronic image products. Images are produced from the best available original document. 
Chemical Separations Processes

for Plutonlum and Uranium (TID-4500, 30th Ed.)

\title{
DISSOLUTION OF ZIRCONIUM ALLOY FUELS \\ IN 309SCb STAINLESS STEEL VESSELS
}

\author{
by \\ Edward S. Occhipinti \\ $J$. Harding Owen \\ Work done by \\ V. P. Caracc1010 \\ E. S. Occhipinti \\ P. M. Kranzlein \\ Approved by \\ D. S. Webster, Research Manager \\ Separations Engineering Division
}

June 1964

\author{
E. I. DU PONT DE NEMOURS \& COMPANY \\ SAVANNAH RIVER LABORATORY \\ AIKEN, SOUTH CAROLINA \\ CONTRACT AT (07-2) - 1 WITH THE \\ UNITED STATES ATOMIC ENERGY COMMISSION
}




\begin{abstract}
Tests were made to define the conditions for dissolving zirconium and zirconium-uranium alloys in $309 \mathrm{SCb}$ stainless steel vessels without excessively corroding the vessels. The optimum dissolvent found was an agitated solution of $1 \mathrm{M} \mathrm{HNO}_{3}$ at $70^{\circ} \mathrm{C}$ with a small stream of concentrated hydrofluoric acid injected continuously near the agitator. Under these conditions, ten tons of zirconium alloy can be dissolved in successive charges over a perlod of two to three weeks with less than one mil of vessel corrosion.
\end{abstract}




\section{CONTENTS}

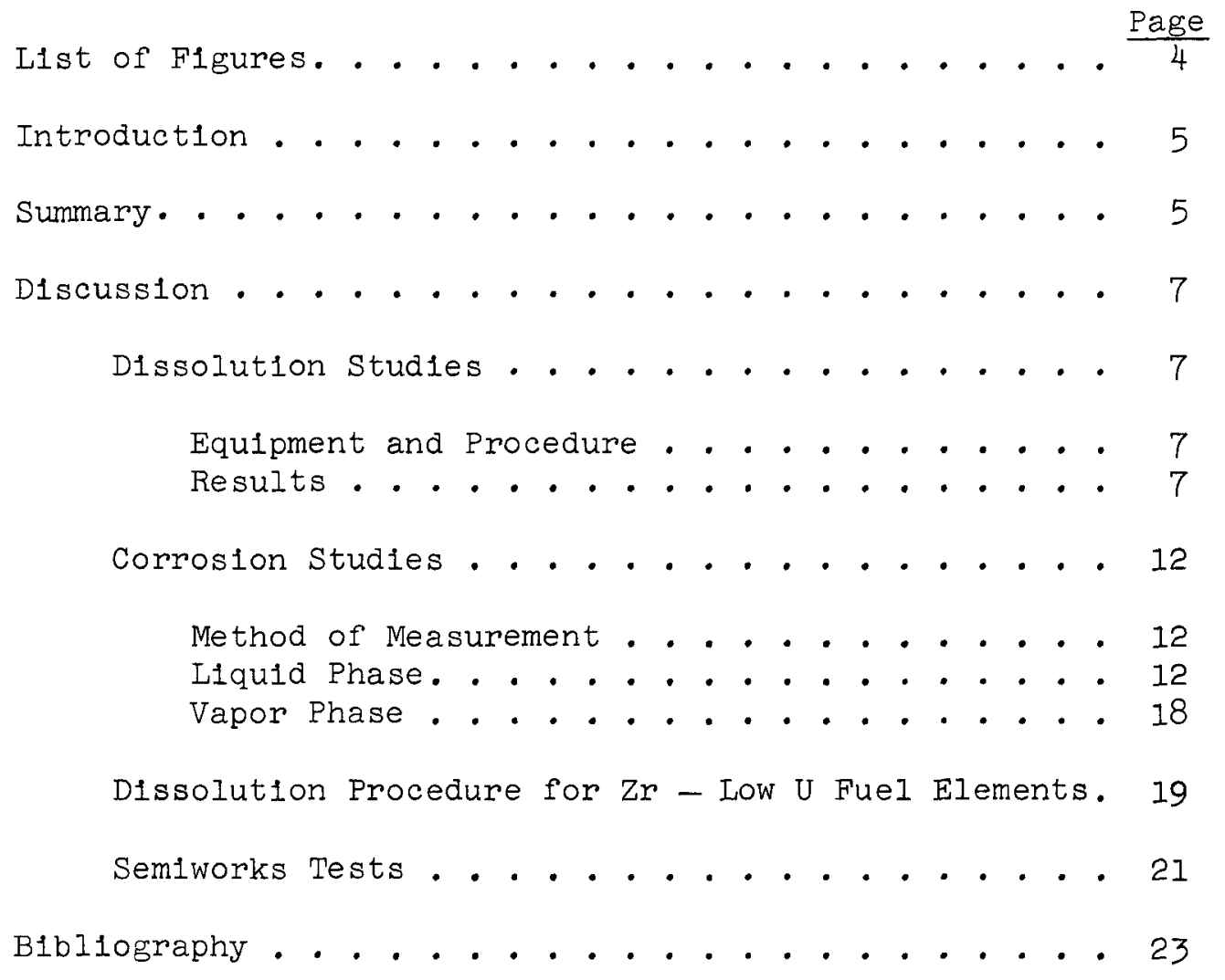




\section{LIST OF FIGURES}

F1gure

$\underline{\text { Page }}$

1 Effect of Agitation Intensity on Dissolution Rate of Zirconium in HF. . . . . . . . 8

2 Dissolution Rates of Zirconium and Zircaloy-2

In $\mathrm{HF}-\mathrm{HNO}_{3}$ : $\mathrm{HF}$ Concentration as Continuous Varlable . . . . . . . . . . . . 9

3 Dissolution Rates of Zirconium and Zircaloy-2 in $\mathrm{HF}-\mathrm{HNO}_{3}$ : $\mathrm{HNO}_{3}$ Concentration as Continuous Varlable ............. 10

4 Dissolution Rates of Zirconium and Zircaloy-2 in $\mathrm{HF}^{-} \mathrm{HNO}_{3}$ : Temperature as Continuous Variable 11

5 Corrosion Rate of $309 \mathrm{SCb}$ Stainless Steel in Bolling $\mathrm{HF}_{-} \mathrm{HNO}_{3}$ : $\mathrm{HNO}_{3}$ Concentration as Continuous Variable. . . . . . . . . . 13

6 Corrosion Rate of $3095 \mathrm{Scb}$ Stainless Steel in Bolling $\mathrm{HF}-\mathrm{HNO}_{3}$ : $\mathrm{HF}$ Concentration as Continuous Variable. . . . . . . . . 14

7 Increase in Corrosion of $309 \mathrm{SCb}$ Stainless Steel Welds Relat1ve to Wrought Metal. . . . . . 15

8 Corrosion Rate of $309 \mathrm{SCb}$ Stainless Steel in $\mathrm{HF}_{-} \mathrm{HNO}_{3}$ : Temperature as Continuous Variable . 16

9 Corrosion Rate of $309 \mathrm{SCb}$ Stainless Steel in $\mathrm{HF}-\mathrm{HNO}_{3}$ at 24,40 , and $60^{\circ} \mathrm{C}: \mathrm{HF}$ Concentration as Continuous Variable . . . . . . . . 17

10 Dissolution of Zircaloy-2 and Corrosion of $309 \mathrm{SCb}$ Stainless Steel Welds in $\mathrm{HF}_{-\mathrm{HNO}_{3}} \cdot$. . 20 


\section{DISSOLUTION OF ZIRCONIUM ALLOY FUELS}

IN $3095 \mathrm{Cb}$ STAINLESS STEEL VESSELS

\section{INTROCUCTION}

The object of this work was to define a dissolution process for zirconium alloy fuels, particularly those fuels with low uranium content. The defined process should be sultable for use in $309 \mathrm{SCb}$ dissolvers at Savannah R1ver.

Zirconium-uranium alloy fuels are readily dissolved by boiling hydrofluoric acid in "Monel"* equipment (1) or by mixtures of hydrofluoric and nitric acids in a vessel resistant to this mixture. The addition of nitric acid suppresses the evolution of hydrogen, minimizes precipitation of $\mathrm{UF}_{4}$ by oxidizing uranium to the soluble uranyl form, and dissolves the tin in Zircaloy when the latter is used as cladding (2). Although "Monel" is not a satisfactory material for containing a mixture that includes nitric ac1d, a program of corrosion testing(3) showed that under certain conditions the $309 \mathrm{SCb}$ stainless steel used in the Savannah River dissolvers is moderately resistant to attack by $\mathrm{HF}-\mathrm{HNO}_{3}$ dissolvent.

The aim of the current study was to find whether the conditions of solution composition and temperature that result in low corrosion of the dissolver also result in acceptable rates of dissolution of zirconium-uranium alloys.

\section{SUMMARY}

Existing data were supplemented by additional studies to allow comparison of the dissolving rates of zirconium alloys and the corrosion rate of $309 \mathrm{SCb}$ stalnless steel over a wide range of temperatures and solution compositions. The nitric acid needed for complete dissolution of Zircaloy-2 and zirconium-uranium alloy had previously been shown to have a suppressive effect on corrosion, as long as the nitric acid concentration did not exceed $1.0 \mathrm{M}$. The rates of both dissolution and corrosion were found to vary in proportion to the concentration of uncomplexed hydrogen fluoride, so that the ratio of rates was constant at a given temperature and nitric acid concentration. The data also showed that a decrease in temperature caused a greater fall in corrosion rate than in dissolution rate, and that this improvement in the dissolutionto-corrosion ratio could be retained even though the hydrogen fluoride concentration was increased to return the dissolution rate to a practical value.

*Trademark of International Nickel Co. 
The preceding observations were combined in a procedure tested at the Savannah River semiworks. A small stream of concentrated hydrogen fluoride was added continuously to a dissolver containing Zircaloy-2 plates and $1 \mathrm{M} \mathrm{HNO}_{3}$ at $70^{\circ} \mathrm{C}$. The rat1o of penetration of Zircaloy-2 to penetration of stainless steel was 5000 to 1 , a value that wlll allow the dissolution, in successive batches, of ten tons of zirconium alloy while only one $\mathrm{mll}$ of the $309 \mathrm{SCb}$ welds is corroded from a plant dissolver. The successive dissolutions will require two to three weeks to complete. 


\section{DISCUSSION}

\section{DISSOLUTION STUDIES}

\section{Equipment and Procedure}

Dissolution rates of unirradiated reactor-grade zirconium and Zircaloy-2 in $\mathrm{HF}-\mathrm{HNO}_{3}$ solutions were measured at the bolling point and below the bolling point. Below-bolling tests were made in a 2-liter dissolver made of polyethylene; the dissolver contained a 4-bladed paddle, 2 inches long and $1 / 2$ inch high, made of Saran. The dissolver assembly was kept in a constant temperature bath and normally contalned 1.5 liters of test solution. Measurements at the bolling point were made in a "Teflon"-lined* vessel, 1-3/4 inches in diameter and 12 inches high, which was fitted with a reflux condenser made of polyethylene; the vessel was normally fllled with $400 \mathrm{cc}$ of solution.

Metal samples were suspended on a polyethylene or "Teflon" holder positioned approximately half an inch from the top of the paddle blades for dissolutions at $35^{\circ} \mathrm{C}$ and $60^{\circ} \mathrm{C}$. Mechanical agitation was not used for dissolution at bolling temperatures. The samples were periodically removed from solution, rinsed, dried, welghed, and measured.

Samples tested in solutions containing less than $0.2 \mathrm{M} \mathrm{HF}$ were pretreated in $\mathrm{HF}_{-} \mathrm{HNO}_{3}$ mixtures to avold major variations in surface roughness during initial dissolving. Good reproduclbility was obtained in this manner. This procedure was not necessary at higher hydrofluoric acid concentrations, since a surface of constant roughness was generated rapidiy. Most of the samples were cut from flat plate that was polished to a 320-grit finish.

\section{Results}

Effect of Agitation. The dissolution rate of zirconium below bolling temperatures was affected appreclably by agltation. With low concentrations of hydrofluoric acid the relative change in rate was much greater than with high con-

*"Teflon" is a trademark of E. I. du Pont de Nemours \& Co. for fluorocarbon resins. 
centrations, as shown in Figure 1. The difference is attributed to the high off-gas rate and consequent high degree of agitation at the metal surface when zirconium is dissolved in strong solutions of hydrofluoric acid. Paddle tip velocities greater than $10 \mathrm{ft} / \mathrm{sec}$ had little additional effect on the rate, and all subsequent measurements below the bolling point were made at this tip velocity.

Effect of Ac1d Concentration and Temperature. No differences could be found in the dissolution rates of reactor-grade zirconium and zircaloy-2 in bolling nitric acid containing

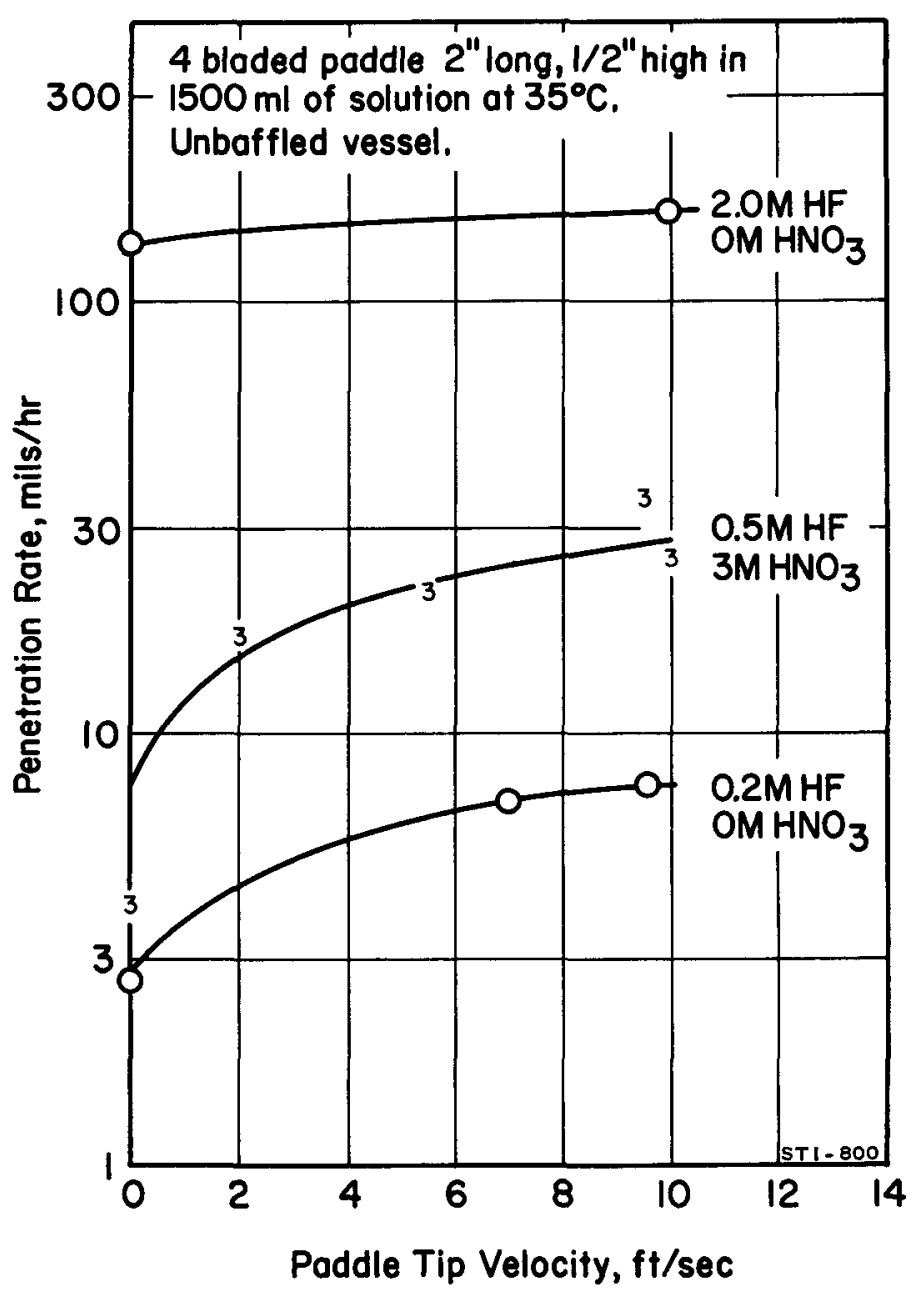

FIG. 1 EFFECT OF AGITATION INTENSITY ON DISSOLUTION RATE OF ZIRCONIUM IN HF 
hydrofluoric ac1d; the two forms of zirconium are treated as one in the following discussion.

At the bolling point, the nitric acid concentration had only a slight effect on the dissolution rate (F1gure 2). At temperatures below bolling, 3M $\mathrm{HNO}_{3}$ increased the dissolution rate about a factor of two at $0.07 \mathrm{M} \mathrm{HF}$, but had no effect at 1.OM HF. Concentrations of nitric ac1d in excess of about $3 \mathrm{M}$ had little additional effect on the dissolution rate of zirconium in dilute hydrofluoric acid at $35^{\circ} \mathrm{C}$, as shown in

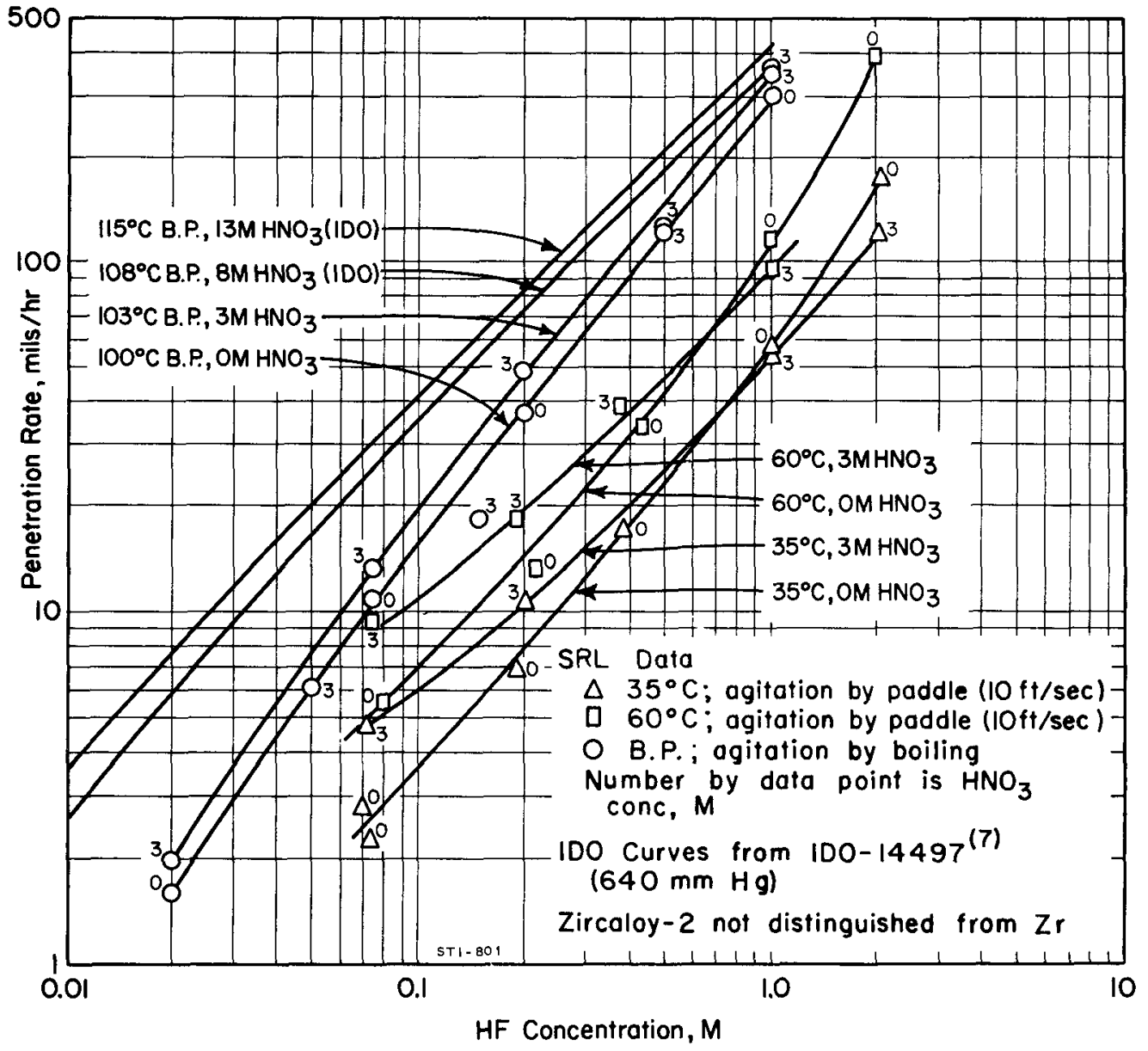

FIG. 2 DISSOLUTION RATES OF ZIRCONIUM AND ZIRCALOY - 2 IN HF-HNO HF CONCENTRATION AS CONTINUOUS VARIABLE 
F1gure 3. The samples had a dark finish when pickled in dilute hydrofluoric acid without nitric ac1d, but the surface acquired a luster when nitric acid was present. When the samples were viewed under a microscope, the dark surface appeared to consist of finely divided particles of metal and therefore to have a higher true surface area than that on the samples treated with mixed acid.

The effect of temperature on the dissolution rate is shown In Figure 4; an activation energy of $5.3 \pm 0.6 \mathrm{kcal} /$

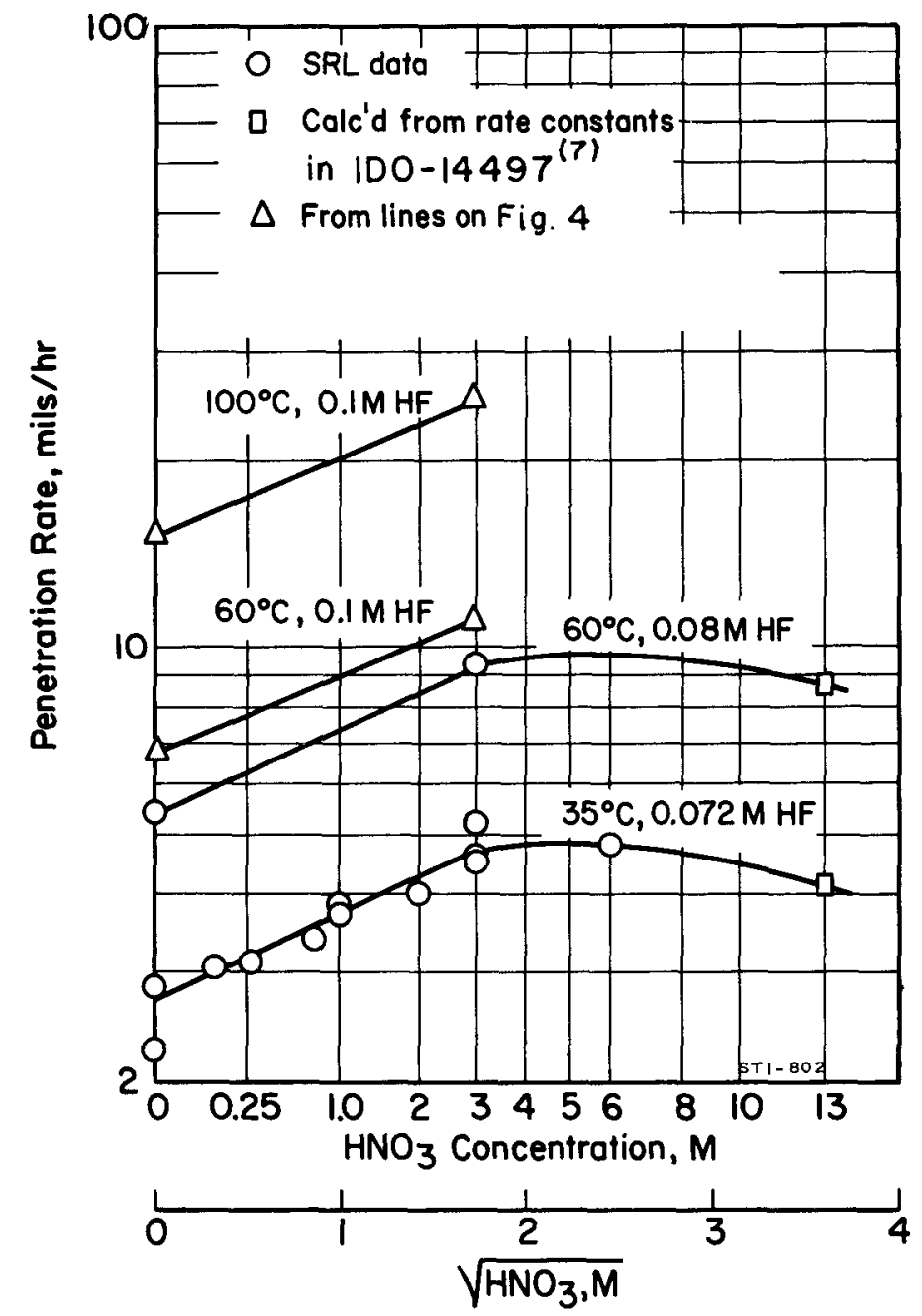

FIG. 3 DISSOLUTION RATES OF ZIRCONIUM AND ZIRCALOY - 2 IN HF-HNO $\mathrm{HNO}_{3}$ CONCENTRATION AS CONTINUOUS VARIABLE 
( $\mathrm{g}$ mol) was calculated from the slope of the lines shown. The activation energies were the same for systems with and without nitric acid.

The dissolution rate of unirradiated $\mathrm{Zr}-9.5 \% \mathrm{U}$ alloy in bolling solutions of hydrofluoric acid in the absence of nitric ac1d was about $65 \%$ of that for reactor-grade zirconium. The data are not shown.

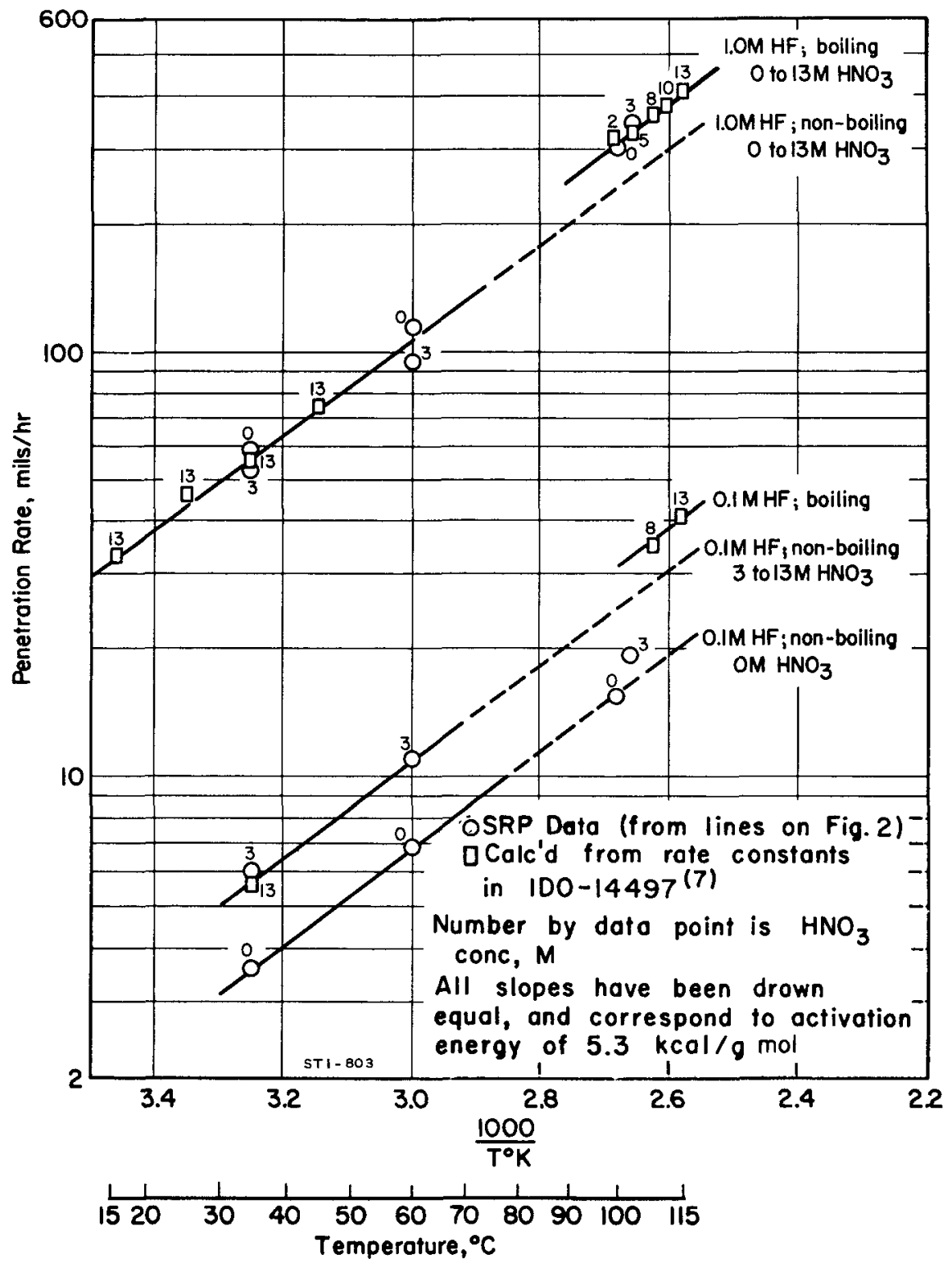

FIG. 4 DISSOLUTION RATES OF ZIRCONIUM AND ZIRCALOY-2 IN HF-HNO TEMPERATURE AS CONTINUOUS VARIABLE 


\section{CORROSION STUDIES}

Method of Measurement

Corrosion rates of $304 \mathrm{~L}$ and $309 \mathrm{SCb}$ stainless steels were measured by determining the loss in welght of samples of known surface area in solutions containing $\mathrm{HF}, \mathrm{HNO}_{3}, \mathrm{Al}, \mathrm{U}$, and $\mathrm{Zr}$ (method described in DP-486(3)). To conform w1th equipment in the separations plant at Savannah River, wrought $304 \mathrm{I}$ was "Heliarc"* welded with 308L flller rod, and $309 \mathrm{SCb}$ was metalarc welded with $309 \mathrm{SCb}$ filler rod.

\section{L1quid Phase}

The corrosion tests were conducted in a "Teflon"-lined vessel, 1-3/4 inches in diameter and 12 inches high; a glass reflux condenser was used for tests at the bolling point.

The corrosion rates of both welded and wrought $309 \mathrm{SCb}$ stainless steel in bolling mixtures of $\mathrm{HF}_{-} \mathrm{HNO}_{3}$ pass through minimum values as the nitric acid concentration is increased from zero up through $0.5 \mathrm{M}$, at constant hydrofluoric ac1d concentration (F1gure 5). In contrast, the rates of corrosion at constant nitric acid concentration increase without minima as the hydrofluoric acld concentration is increased (Figure 6). Metal-arc welds of $309 \mathrm{SCb}$ are preferentially attacked in bolling mixtures containing nitric acid, although the attack is not pronounced unt11 the concentration exceeds 1.OM (Figure 7).

The effect of temperature on the corrosion rate of $309 \mathrm{SCb}$ stainless steel 1s shown in Figure 8; for several concentrations of hydrofluoric and nitric acids, an activation energy of 13.3 $\mathrm{kcal} /(\mathrm{g} \mathrm{mol})$ was calculated from the slope of the lines shown. Most of the points on Figure 8 were taken from lines drawn through the experimental data on Figure 9. The latter 1lius. trates the effect of hydrofluoric acld concentration on the corrosion rate of $309 \mathrm{SCb}$, with temperature and nitric acid concentration as parameters. The most significant feature of the corrosion versus temperature relationship on Figure 8 compared to the relationship for zirconium dissolution on Figure 4 is that lowering the temperature decreases corrosion of $309 \mathrm{SCb}$ stainless steel more than it decreases the dissolution of zirconium.

*A registered trademark of Union Carbide and Carbon Corp. 


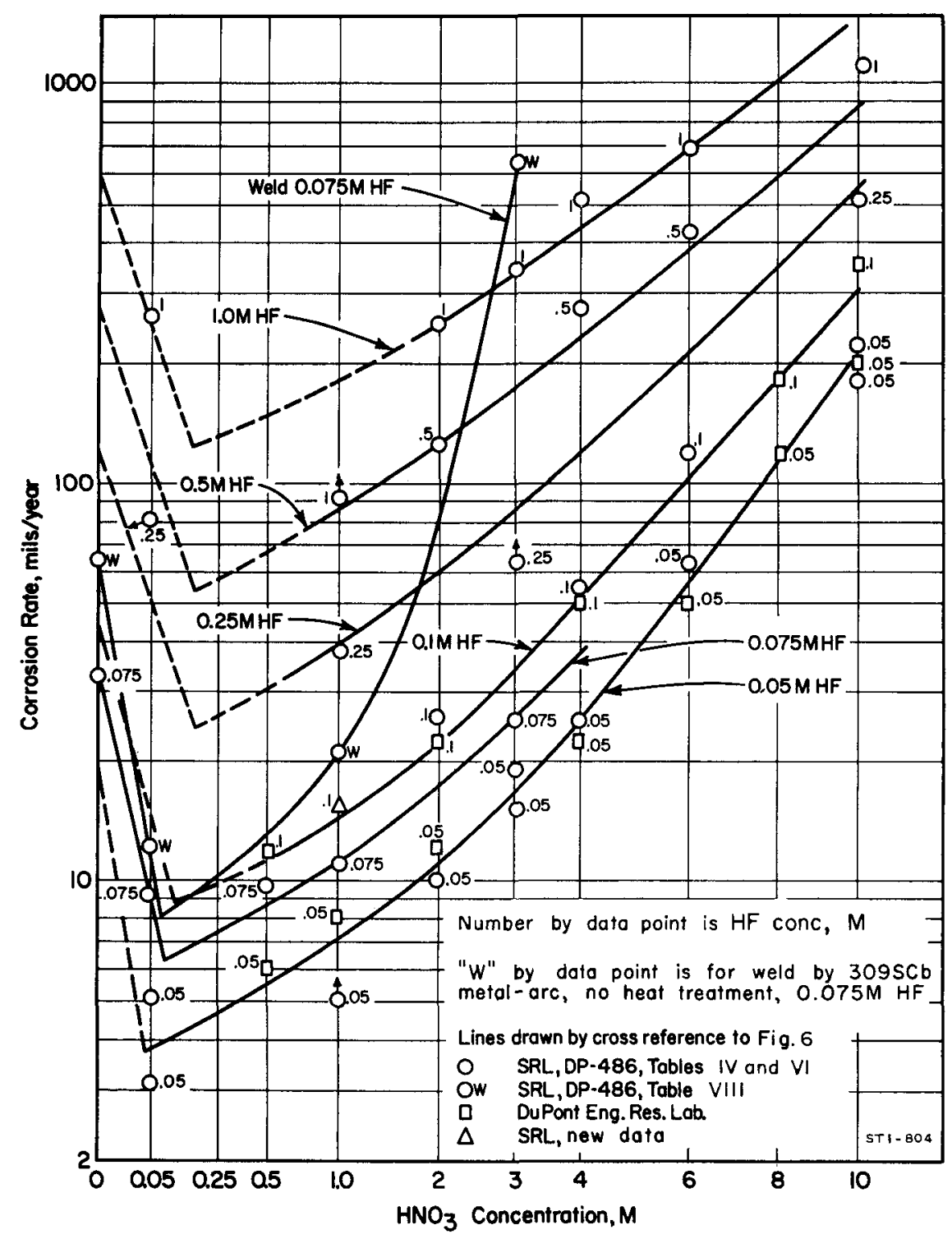

FIG. 5 CORROSION RATE OF 309SCb STAINLESS STEEL IN BOILING HF-HNO $\mathrm{HNO}_{3}$ CONCENTRATION AS CONTINUOUS VARIABLE 


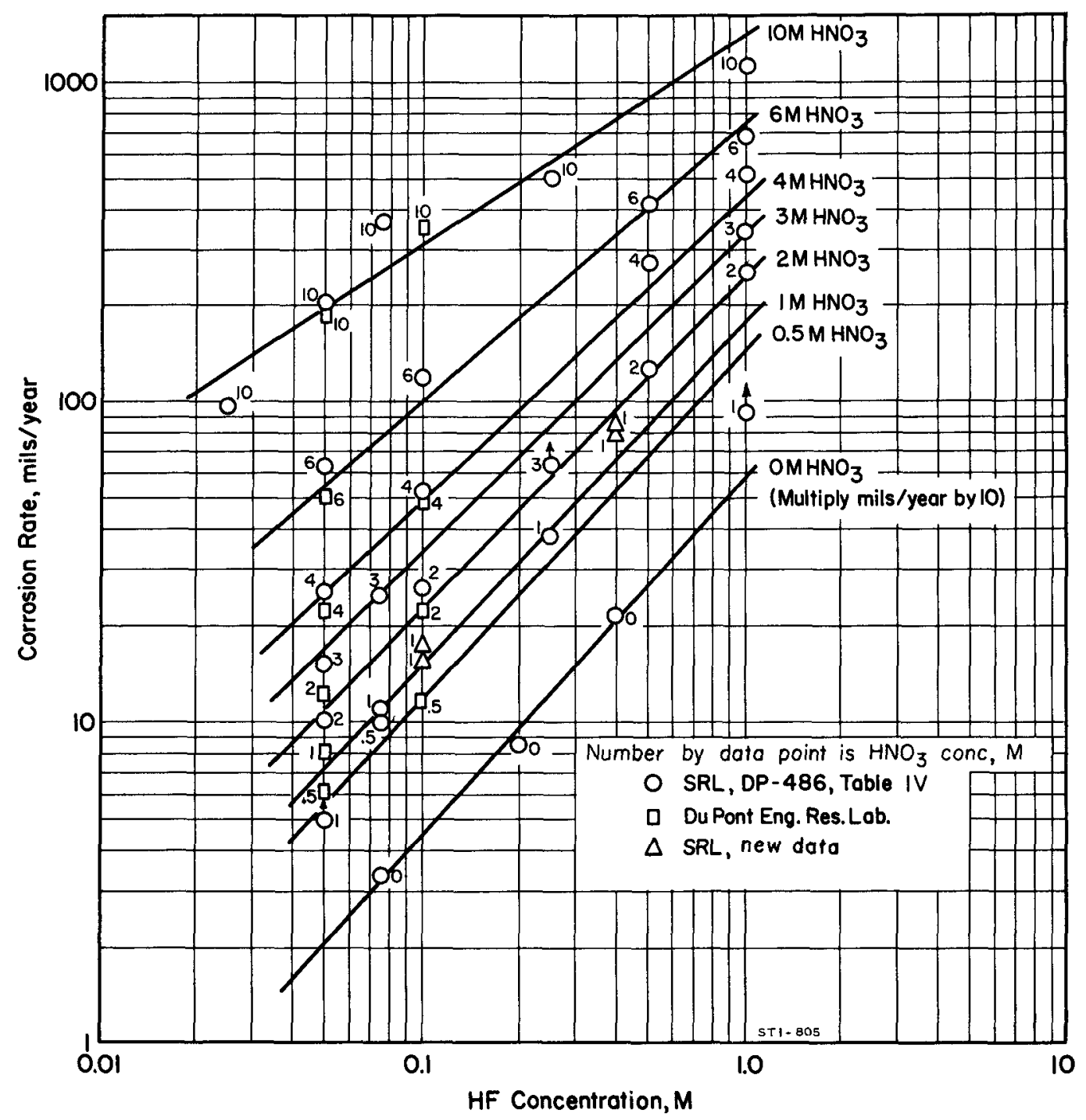

FIG. 6 CORROSION RATE OF 309SCb STAINLESS STEEL IN BOILING HF-HNO HF CONCENTRATION AS CONTINUOUS VARIABLE 


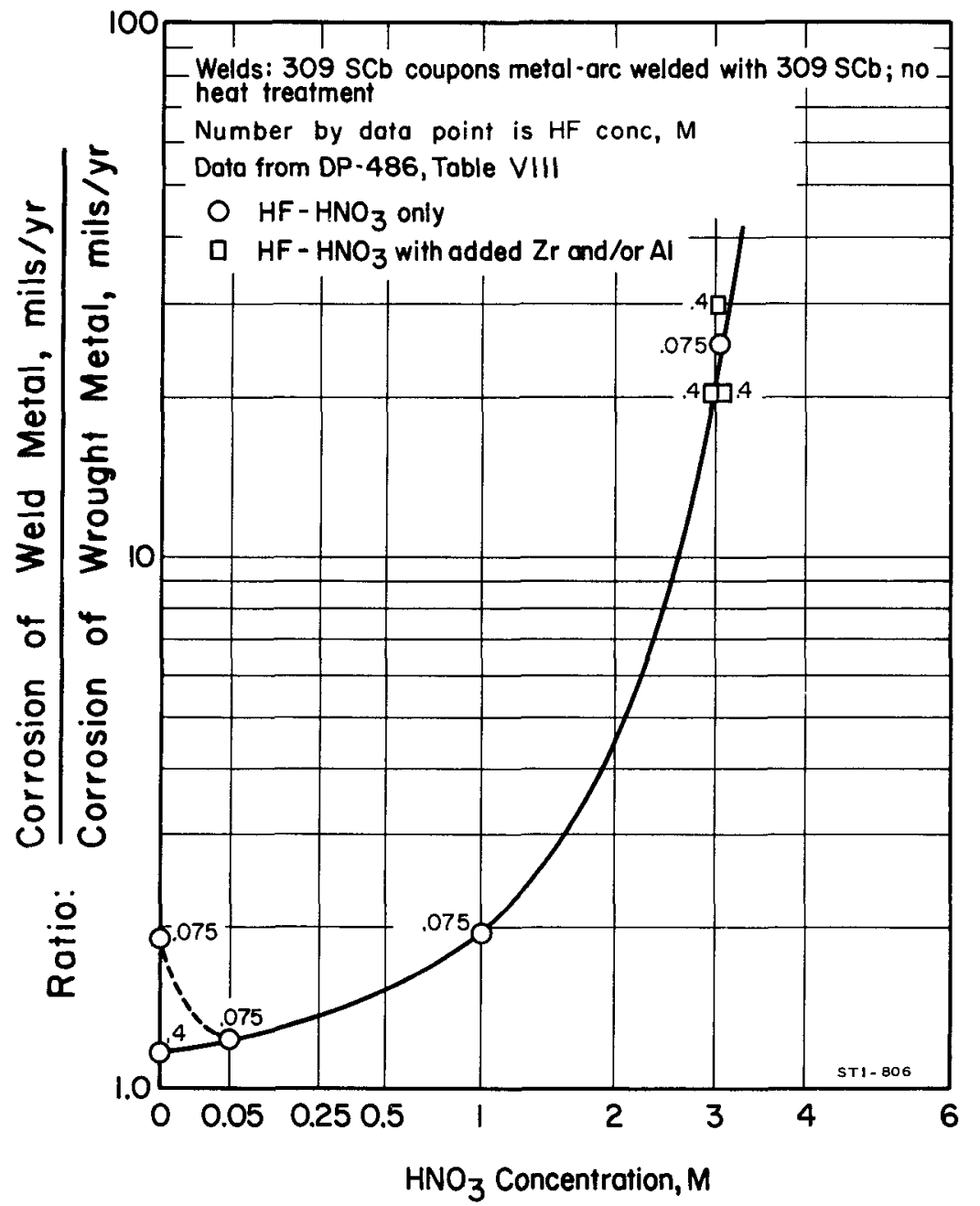

FIG. 7 INCREASE IN CORROSION OF 309SCb STAINLESS STEEL WELDS RELATIVE TO WROUGHT METAL 


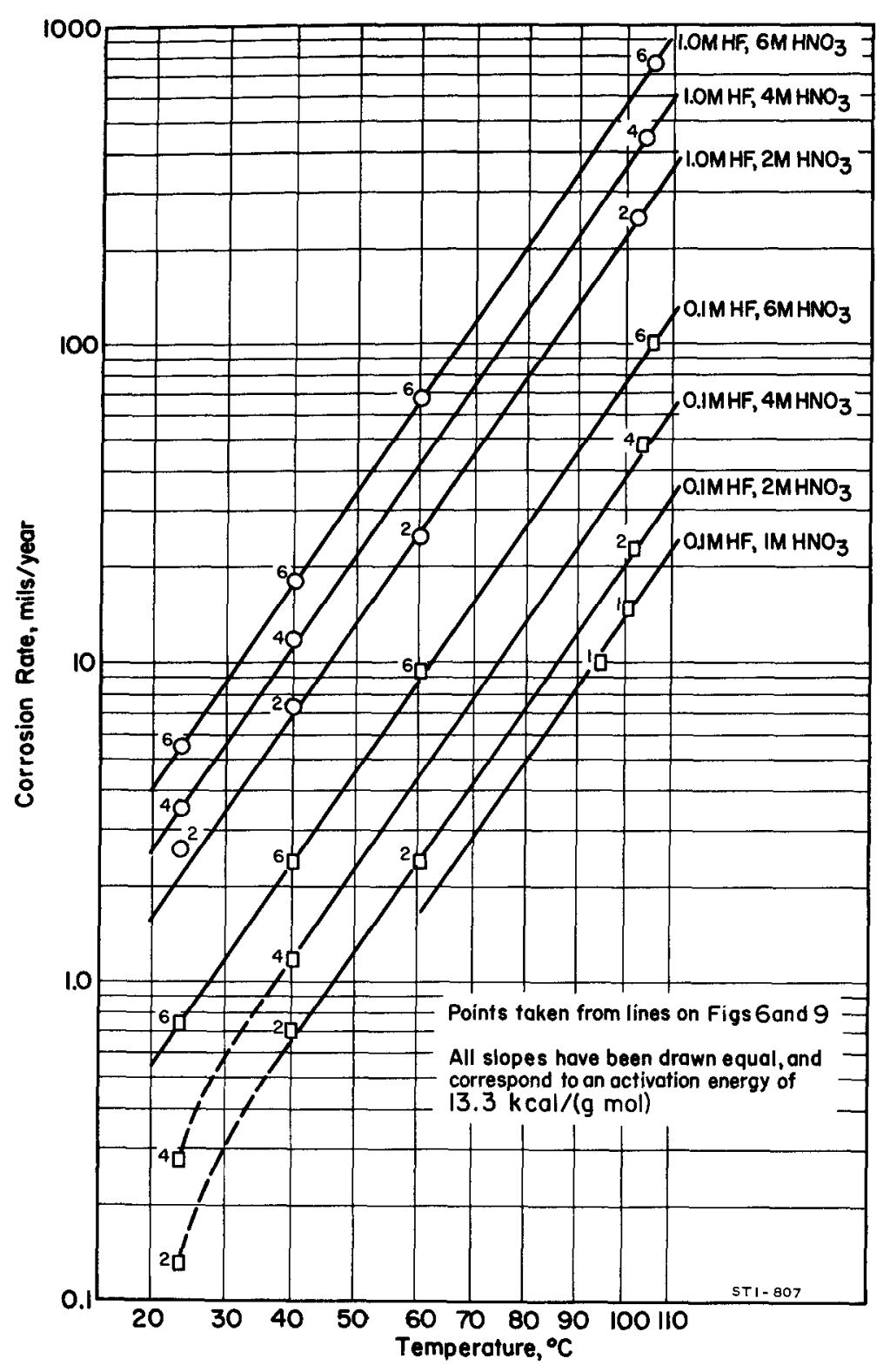

FIG. 8 CORROSION RATE OF 309SCb STAINLESS STEEL IN HF-HNO TEMPERATURE AS CONTINUOUS VARIABLE 


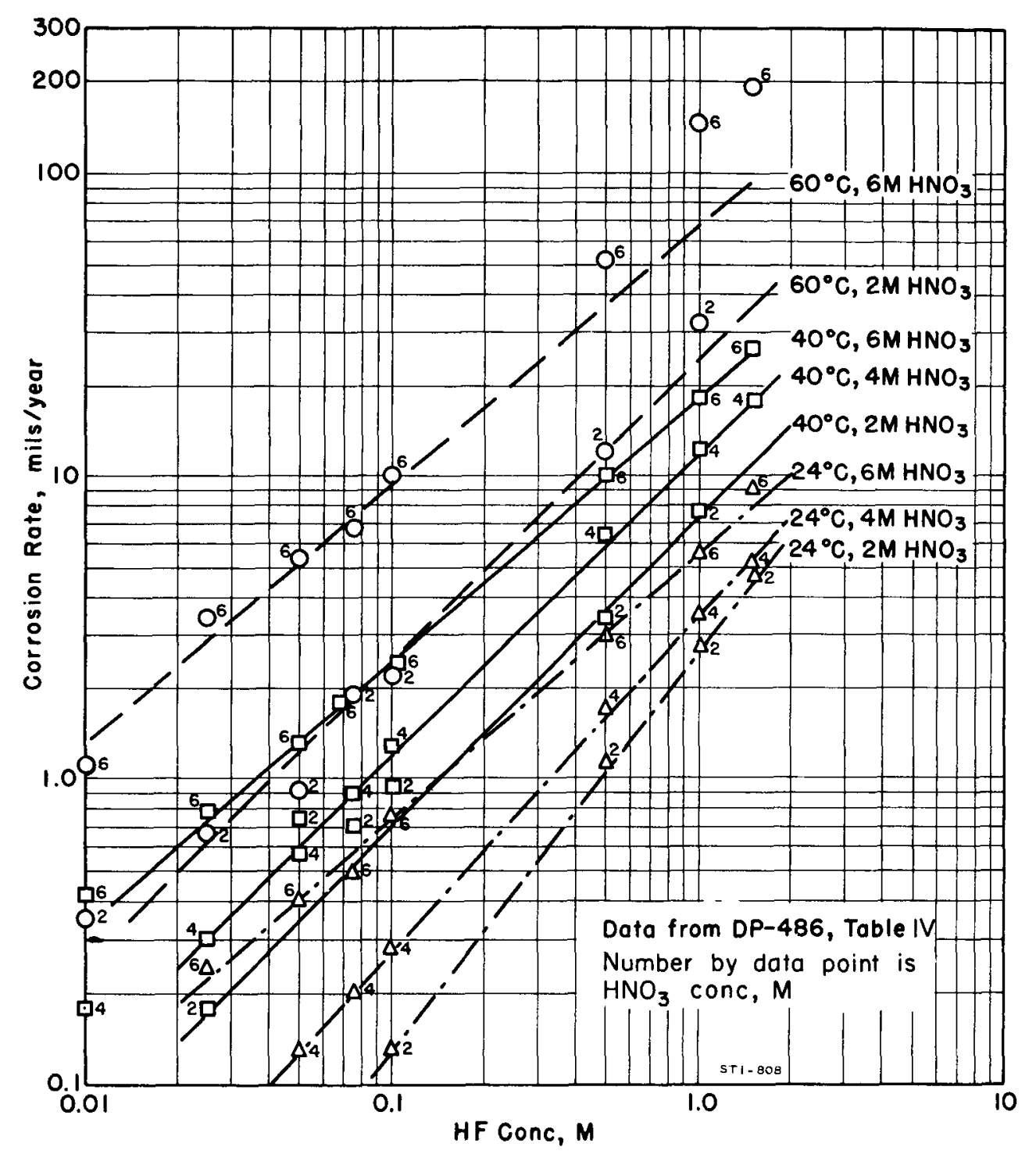

FIG. 9 CORROSION RATE OF $309 \mathrm{SCb}$ STAINLESS STEEL IN HF-HNO 3 AT 24,40 , AND $60^{\circ} \mathrm{C}$ : HF CONCENTRATION AS CONTINUOUS VARIABLE 


\section{Vapor Phase}

The corrosion of $309 \mathrm{SCb}$ stainless steel was measured in the vapor phase above mixtures of $\mathrm{HF}, \mathrm{HNO}_{3}$, and $\mathrm{Zr}$ at various boilup rates (Table I). A bollup rate of $1.3 \mathrm{~g} /(\mathrm{hr})\left(\mathrm{cm}^{2}\right)$ approximates that expected during plant-scale dissolution. Test coupons placed in the vapor phase of the equipment are actually exposed to a mixture consisting of condensate from the reflux condenser, entralnment, and dry vapor from the boiling liquid. Corrosion rates of $309 \mathrm{SCb}$ stainless steel in the vapor phase are considerably less than in the liquid phase at plant bollup rates.

Since inexplicably high rates of corrosion in the vapor phase were measured at the high bollup rates (Table I), an experiment was undertaken to clarify the results. A $10 \%$ fraction of the dissolver solution was removed by single-stage distillation from a mixture of $\mathrm{IM} \mathrm{HNO}_{3}, 2.6 \mathrm{M} \mathrm{HF}$, and $0.5 \mathrm{M} \mathrm{Zr}$ and used for corrosion tests of $309 \mathrm{SCb}$. The corrosion rates in both the bolling liquid and the vapor phase of this fraction were below the limits of measurement. It was concluded that the high corrosion rates in the vapor phase at the high bollup rates were caused by entrained salt that concentrated on the test coupon. This conclusion is corroborated by data from the low-bollup experiments: when an a1r sweep was used, the corrosion rate of samples in the vapor phase was greater than without the air sweep, presumably because of faster concentration by evaporation of the small amounts of entrainment.

TABLE I

\begin{tabular}{|c|c|c|c|c|c|c|}
\hline \multirow{2}{*}{$\begin{array}{c}\mathrm{HF}, \\
\mathrm{M} \\
\end{array}$} & \multirow{2}{*}{$\begin{array}{r}\mathrm{Zr}, \\
\mathrm{M}\end{array}$} & \multirow{2}{*}{$\begin{array}{l}\text { Temp, } \\
{ }^{\circ} \mathrm{C} \\
\end{array}$} & \multirow{2}{*}{ Bo1lup (a) } & \multirow{2}{*}{$\begin{array}{l}\text { Alr Sweep, } \\
\mathrm{cc} /(\mathrm{hr})\left(\mathrm{cm}^{2}\right)\end{array}$} & \multicolumn{2}{|c|}{$\begin{array}{c}\text { Corrosion Rate, } \\
\text { mils/yr }\end{array}$} \\
\hline & & & & & Liquid & Vapor \\
\hline 0.1 & 0 & 95 & None & 0 & 10 & 1 \\
\hline 0.1 & 0 & 95 & None & 385 & 10 & 1 \\
\hline 0.1 & 0 & $\mathrm{BP}(\mathrm{b})$ & Low & 0 & 16 & 1 \\
\hline 0.1 & 0 & $\mathrm{BP}$ & Low & 385 & 14 & 2 \\
\hline 0.4 & 0 & $\mathrm{BP}$ & LOW & 0 & 83 & 6 \\
\hline 1.1 & 0.2 & 95 & None & 0 & 19 & 1 \\
\hline 1.1 & 0.2 & 95 & None & 385 & 17 & 3 \\
\hline 1.1 & 0.2 & $B P$ & Low & 0 & 30 & 1 \\
\hline 1.1 & 0.2 & $B P$ & Low & 385 & 27 & 7 \\
\hline 0.1 & 0 & $\mathrm{BP}$ & H1gh & 0 & 17 & 8 \\
\hline 0.4 & 0 & $B P$ & High & 0 & 77 & 112 \\
\hline 1.0 & 0.15 & $\mathrm{BP}$ & High & 0 & 52 & 78 \\
\hline 1.1 & 0.2 & $\mathrm{BP}$ & H1gh & 0 & 34 & 57 \\
\hline 2.0 & 0.4 & BP & $\mathrm{HIgh}$ & 0 & 59 & 147 \\
\hline 3.0 & 0.65 & BP & $\mathrm{HIgh}$ & 0 & 43 & 282 \\
\hline
\end{tabular}

(a) Low bo1lup $=1.3 \mathrm{~g} /(\mathrm{hr})\left(\mathrm{cm}^{2}\right)$; h1 gh bollup $=13 \mathrm{~g} /(\mathrm{hr})\left(\mathrm{cm}^{2}\right)$

(b) $\mathrm{BP}=$ boillng point 


\section{DISSOLUTION PROCEDURE FOR $\mathrm{Zr}$ - LOW U FUEL ELEMENTS}

The $\mathrm{Zr}$ - Iow $\mathrm{U}$ alloys can be dissolved at $60^{\circ} \mathrm{C}$ or lower by continuousiy feeding concentrated hydrofluoric acid to the dissolver through a "Hastelloy" $F^{*}$ line that extends below the liquid level. Agltation is necessary since operation is below the bolling point. The hydrofluorlc acid should be added at a unfform rate throughout the dissolution period. The rate of addition is chosen to give a rate of reaction that does not exceed the heat-removal and off-gas capacity. For complete dissolution, 5 mols of hydrofluoric acid must be added for each mol of zirconlum charged. Clear and stable dissolver solutions, prepared by dissolving unirradiated $\mathrm{Zr}-$ low $U$ fuel on a laboratory scale, contained about $0.5 \mathrm{M}$ $\mathrm{Zr}, 0.4 \mathrm{M} \mathrm{NO} \overline{3}$, and $2.5 \mathrm{M} \mathrm{HF}$.

The preferential attack of $\mathrm{HF}-\mathrm{HNO}_{3}$ solutions upon metalarc welds of $309 \mathrm{SCb}$ stalnless steel is very dependent upon nitric acid concentration; $1 \mathrm{M} \mathrm{HNO}_{3}$ appears to be the optimum concentration when dissolving in $309 \mathrm{SCb}$ stalnless steel equipment. In practice hydrofluoric acid is added to a solution that is initially IM in nitric acid; the final nitric acid concentration w1ll be about $0.4 \mathrm{M}$. The quantity of fuel charged is adjusted to yield a solution of about $0.5 \mathrm{M} \mathrm{zr}$.

In Figure 10 the dissolution rate of Zircaloy-2 is compared with the corrosion rate of $309 \mathrm{SCb}$ welds under a variety of conditions. The ratio between dissolution rate and corrosion rate at a given temperature does not change with changes in hydrofluoric acid concentration; that is, an increase in hydrofluoric acid concentration accelerates both processes to the same degree. Consequently whether hydrogen fluoride concentration leads to fast or slow dissolution, the amount of vessel corrosion remains proportional to the thickness of Zircaloy penetrated, and thus to the number of charges dissolved. Furthermore, the ratio of dissolution to corrosion is not influenced by disappearance of fluoride to form a complex with dissolved zirconium, since both rates are affected equaliy.

Solutions downstream from the dissolver at Savannah River are processed in equipment made of $304 \mathrm{~L}$ stalnless steel. Typical solutions would contain $\mathrm{HF}, \mathrm{HNO}_{3}, \mathrm{U}$, and $\mathrm{Zr}$, with $\mathrm{Al}$ added to complex the free fluoride remaining after zirconium dissolution. (Uranium has been found to have little effect on corrosion ${ }^{(4)}$. The fluoride complexing powers of several cations are described in ORNL-2713(5).) The rate of corrosion of wrought $304 \mathrm{~L}$ welded with $308 \mathrm{~L}$ in typical aluminum-containing

\footnotetext{
* "Hastelloy" is a trademark of Haynes Stellite Co., Division
} of Union Carbide Corp., Kokomo, Ind. 


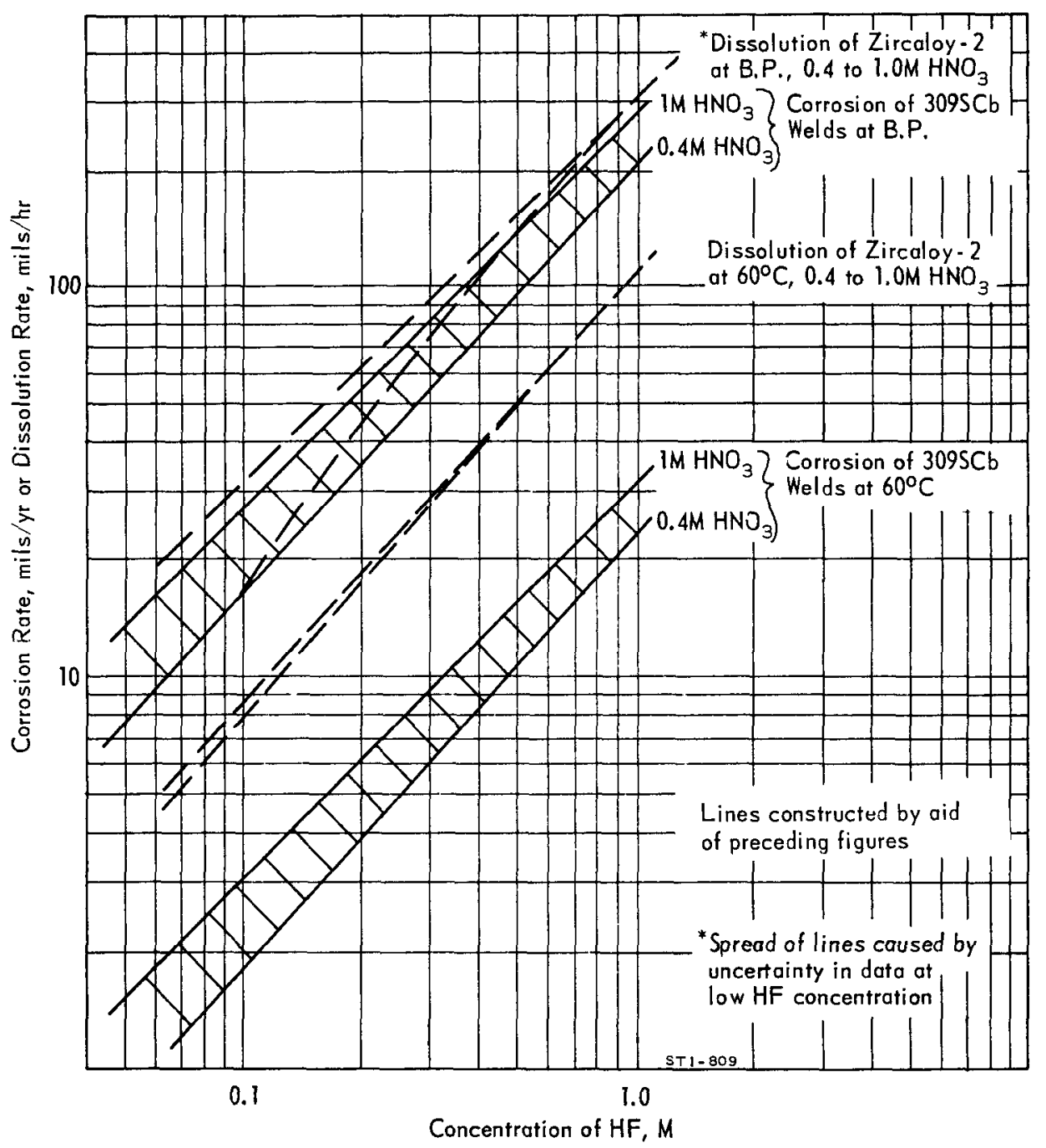

FIG. 10 DISSOLUTION OF ZIRCALOY - 2 AND CORROSION OF $309 \mathrm{SCb}$ STAINLESS STEEL WELDS IN HF $-\mathrm{HNO}_{3}$

solutions at $40^{\circ} \mathrm{C}$ is less than $10 \mathrm{mlls} / \mathrm{yr}^{(3)}$. Boiling solutions contalning uncomplexed fluoride are very corrosive to $304 \mathrm{I}$ stainless steel and have been used to dissolve $304 \mathrm{~L}$ cladding $(2)$. Even at $40^{\circ} \mathrm{C}$, the corrosion rate with the uncomplexed fluoride is 200 to $500 \mathrm{mlls} / \mathrm{yr}$.

During a typical dissolution of $\mathrm{Zr}$ - low $U$ fuel the average composition of the off-gas downstream from the reflux condenser was $8 \% \mathrm{H}_{2}, 18 \% \mathrm{~N}_{2}, 50 \% \mathrm{NO}, 23 \% \mathrm{~N}_{2} \mathrm{O}$, and $1 \%$ miscellaneous gases. The nitric acld not only reduces the corrosion of wrought and welded $309 \mathrm{SCb}$ stalnless steel (Figure 5), but also suppresses the evolution of hydrogen from the reaction of zirconium with hydrofluoric acid. Alr can be used to dilute the off-gas to less than $4 \% \mathrm{H}_{2}$. The air flow rate required depends upon the maximum surface of 
metal exposed during dissolution. If a penetration rate of $10 \mathrm{mils} / \mathrm{hr}$ and a gas evolution rate of $1.5 \mathrm{mols}$ per mol of zirconium dissolved are assumed, the maximum off-gas rate per square foot of surface is about 0.033 SCFM (standard cublc feet per minute).

\section{SEMIWORKS TESTS}

The successful dissolution of Zircaloy-2 plates in bolling IM $\mathrm{HNO}_{3}$ to which concentrated hydrofluoric acid was slowly added is described in DP-519(6). A 27.5-1b charge was dissolved in 12.5 hours. The free fluoride did not exceed $0.12 \mathrm{M}$, and the corrosion rate of $309 \mathrm{SCb}$ stainless steel coupons was $25-30 \mathrm{mils} / \mathrm{yr}$.

A fuel element made of four plates of $\mathrm{Nb}-\mathrm{U}$ alloy clad with Zircaloy-2 was used to demonstrate dissolution below the bolling point (the $\mathrm{Nb}-\mathrm{U}$ element was the only type avallable at the time). The test plates were $4.5 \mathrm{ft}$ long and 1.4 inches wide, and were aligned with a plate-toplate clearance of $70 \mathrm{mils}$. Autoclaving had left a tight, black film of oxide on the surface.

The element was submerged in $1 \mathrm{M} \mathrm{HNO}_{3}$ at $70^{\circ} \mathrm{C}$, and the acid was circulated through the housing by the steam jet at $2 \mathrm{gal} / \mathrm{min}$ ( $1 \mathrm{ft} / \mathrm{sec}$ within the small clearance between plates). 309SCb metal-arc-welded corrosion coupons were placed in the housing, in the bulk solution, and in the vapor space. Hydrofluoric ac1d (30M) in excess of the 5 mols per mol of zirconium required was added at a controlled rate directly to the jet suction.

Six runs were made with the hydrofluoric acid addition rate varied between 1 and 2 liters/hr; the fluoride uncomplexed with zirconium varied between 0.4 and $1.2 \mathrm{M}$. As expected, the rate of attack on both Zircaloy-2 and stainless steel increased with higher hydrofluoric acid concentrations; a typlcal result at low hydrofluoric acid concentration was $18 \mathrm{mils} /$ hour on the Zircaloy-2 and $25 \mathrm{mils} /$ year on the steel. The temperature inside the container at the jet discharge was $80^{\circ} \mathrm{C}$, and the rate of corrosion of the coupons in this vicinity was $320 \mathrm{mils} / \mathrm{yr}$ ( 13 times the rate in the bulk I1quid). The coupons in the vapor phase corroded at rates of less than $10 \mathrm{mils} / \mathrm{yr}$. As expected, the $\mathrm{Nb}-\mathrm{U}$ alloy did not dissolve, but the Zircaloy-2 cladding and edge guides disappeared in 3.5 to 7 hours, depending on the hydrofluoric acid concentration. Inspection after one hour of exposure showed that the cladding had not been appreclably attacked, although the edge guides were dissolving. Subsequent laboratory tests showed that the black oxide film 
on the surface of the Zircaloy-2 was not attacked for about 1.5 hours; in contrast, the edge guides, wh1ch had been machined after autoclaving, had no protective film to delay the attack. This 1.5-hour induction period added 15$20 \%$ to the time cycle.

The tests showed that the Zircaloy-2 dissolved 4000 to 6000 times as rapidly as the stainless steel corroded; this rat1o is satisfactory. The data indicate that instantaneous rates of corrosion between 25 and $50 \mathrm{mils} / \mathrm{yr}$ may be expected in the plant dissolvers. In practice, about $300 \mathrm{~kg}$ of zlrconium w1Il be dissolved in a typical cycle of 10 to 12 hours, so that less than $1 \mathrm{mll}$ would be corroded from the most sensitive parts (the welds) of the dissolver for every 10 tons of zirconium fuel dissolved. 


\section{BIBLIOGRAPHY}

1. Reid, D. G., et al. "Reprocessing of Fuel Containing Z1rconlum". Proc. U. N. Intern. Conf. Peaceful Uses Atom1c Energy, 2nd, Geneva, 17, 145-53 (1958).

2. Maness, R. F. Power Reactor Fuels Reprocessing. Progress Report on Corrosion Studies. General Electric Co., Hanford Atomlc Products Operation, Richland, Wash. USAEC Report HW-61662 (1959).

3. Kranzlein, P. M. Corrosion of Sta1nless steel in $\mathrm{HNO}_{3}$-HF Solutions. E. I. du Pont de Nemours \& Co.., Savannah R1ver Laboratory, A1ken, S. C. USAEC Report DP-486 (1960).

4. Occhipint1, E. S. Reprocessing of Power Reactor Fuels, S1xth Quarterly Progress Report, January 1 to April l, 1959. E. I. du Pont de Nemours \& Co., Savannah R1ver Laboratory, Aiken, S. C. USAEC Report DP-393 (1959).

5. Gens, T. A. and F. G. Baird. Modified Zirflex Process for Dissolution of Zirconium- and Niobium-Bearing Nuclear Fuels in Aqueous Fluoride Solutions: Laboratory Development. Oak Ridge National Laboratory, Oak Ridge, Tenn. USAEC Report ORNL-2713 (1959).

6. Meyer, L. H. Reprocessing of Power Reactor Fuels, Eleventh Quarterly Progress Report, Apr11 1 to July 1, 1960. E. I. du Pont de Nemours \& Co., Savannah R1ver Laboratory, A1ken, S. C. USAEC Report DP-519 (1960).

7. Vander, E. M., et al. Dissolution of Z1rconium and Zircaloy-2 in Nitric-Hydrofluoric Ac1d Mixtures at Reflux Temperatures. Phillips Petroleum Co., Atom1c Energy Div1sion, Idaho Falls, Idaho. USAEC Report IDO-14497 (1959). 